\title{
Review of Solvents Based on Biomass for Mitigation of Wax Paraffin in Indonesian Oilfield
}

\author{
M. K. Afdhol ${ }^{1}$, M. Abdurrahman ${ }^{1, *}$, F. Hidayat ${ }^{1}\left({ }^{1}\right.$, F. K. Chong ${ }^{2}{ }^{(D}$ and H. F. Mohd Zaid ${ }^{2}$ \\ 1 Department of Petroleum Engineering, Universitas Islam Riau, Jalan Kaharuddin Nasution No. 113, \\ Pekanbaru 28284, Indonesia; afdhol@eng.uir.ac.id (M.K.A.); fikihidayat@eng.uir.ac.id (F.H.) \\ 2 Department of Fundamental \& Applied Sciences, Universiti Teknologi PETRONAS, Bandar Seri Iskandar \\ 32610, Perak, Malaysia; chongfaikait@utp.edu.my (F.K.C.); hayyiratul.mzaid@utp.edu.my (H.F.M.Z.) \\ * Correspondence: muslim@eng.uir.ac.id
}

Received: 23 October 2019; Accepted: 10 December 2019; Published: 13 December 2019

check for updates

\begin{abstract}
This paper presents a review of the expectations and challenges of using biomass in the prevention and slowing of paraffin wax deposition that takes place during the crude oil production process. The inhibition of the deposition process involves the use of solvents from biomass that are generally available around the crude oil production field. The processes used to scale down the precipitation of wax include mixing crude oil with the manufacturer's solvent composed of toluene and xylene. The goal is to assess solvents sourced from biomass that are capable to slow down the wax deposition process. Wax appearance temperature is an important characteristic to evaluate the possible wax precipitation of a given fluid. Wax precipitation can be reduced by using some chemical additives, often called the pour point depressant. This additive is expected to be produced from local biomass which can compete with solvents currently produced on the market.
\end{abstract}

Keywords: biomass; crude oil; wax appearance temperature; pour point depressant

\section{Introduction}

The decline in crude oil production is a persistent challenge in the oil industry. The rate of production decreases over time, often caused by damage located in both the rock formation and the surface facilities. Close to $85 \%$ of those damages are resultant from oil wax congealing at the wellbore, in production string, and all through the surface pipelines [1]. The majority of crude oil and its products contain large amounts of oil wax called paraffin. Paraffin is a mixture of hydrocarbons formed from linear or normal chains, which are mainly composed of 20 to 40 carbon atoms [2]. Paraffin wax deposition causes equipment failure, upstream and downstream flow congestion, and loss of production, transportation capacity, and storage [3]. Due to the deposition of paraffin wax, plenty of wells are shut-in, countless pipelines blocked, transport vessels taken out of services, and refinery equipment closed at certain times, all resulting in a loss of income [1]. Once formed, the paraffin in which the liquid is transported is deposited on the wall of the pipes.

Paraffin deposition in hydrocarbon production systems is a major challenge for the development of oil and gas fields in cold environments or in deep waters [4-6] where nucleation and adhesion of the wax to the wall of the pipe occur [7]. Paraffin deposition in oil production is a critical problem that is difficult to control in terms of productivity and production operating costs. It begins from the reservoir then progresses to surface facilities [4]. A common method used to mitigate the problem is increasing the temperature of deposit wax. The problem must be handled as early as possible to prevent the decrease in oil production due to solids blocking the flow in the pipe. The primary target of heating the wax is to reduce the viscosity of the fluids. This can also be achieved by the use of some additives. Solvents generated from biomass can act as wax inhibitors. 
Research on the application of biomass has mainly focused on the pharmaceutical industry, fuel reserves, and others [8]. However, there has been little discussion about the application of biomass to the crude oil in below surface conditions or near the wellbore. This study systematically reviews the expectations and challenges of using biomass in the prevention and slowing of paraffin wax deposition that occurs during the crude oil production process. Firstly, the review discusses the availability of raw materials in which the types and the area distribution of each material are shown. Secondly, this paper assesses the bioethanol production process consisting of three steps: pretreatment, hydrolysis, and fermentation. Thirdly, this paper examines the problems that occur due to the appearance of paraffin wax and how the solvent is frequently used in the oil industry. Biomass is a renewable energy source that has received attention; various types of biomass have been used such as coffee grounds [9], tea waste, and palm shells $[10,11]$. Bio-solvents are solvents that can be produced easily and economically where the production process consists of several stages: hydrolysis, fermentation, and the purification process through distillation [12-18]. One type of bio-solvent that can be produced from biomass is bioethanol [19-21]. The raw materials for bioethanol can be sourced from: (1) biomass starch such as corn, cassava, and sorghum [12]; (2) sugar sources, such as cane crops, sugar cane juice, coconut sap, and gum [22,23]; and (3) source of cellulose including rice husks, bagasse, and corncobs [24,25]. In general, biomass basically consists of cellulose, hemicellulose, and lignin $[19,26,27]$ which the availability of its raw materials is a great potential to be utilized.

\section{Availability of Raw Materials}

The use of waste in waste to energy (WTE) technology involves a treatment process to recover energy in the form of heat, electricity, or transportation fuel from waste sources [28]. WTE is used to create various types of products or semi-finished products from various types of waste such as palm oil waste [29,30], coffee grounds [9], and tea pulp, and even the use of nonorganic waste such as plastic waste [10].

Lignocellulosic biomass, such as agricultural residues (corn stovers and wheat straw), wood, and energy crops, is an attractive material for bioethanol fuel production since it is the most abundant renewable resource on earth [31,32]. Lignocellulosic biomass could produce up to 442 billion liters per year of bioethanol [33]. Thus, the total potential bioethanol production from crop residues and waste is 491 billion liters per year, about 16 times higher than the current world bioethanol production. Rice straw is one of the most abundant lignocellulose waste materials in the world, with an annual production of about 731 million tons, which is distributed in Africa (20.9 million tons), Asia (667.6 million tons), Europe (3.9 million tons), the Americas (37.2 million tons), and Oceania (1.7 million tons) [10]. Food waste from the rest of the food production is used as animal feed. Food waste is composed of complex compounds lignin, hemicellulose, and cellulose (lignocellulose), and the compound has the potential to be biologically converted into other compounds so that they can be used as a solvent [34].

\section{Bioethanol Production Process}

Bioethanol is made from lignocellulosic biomass found in waste, where this raw material is available in many environments and is expected to increase the value of the waste [35]. Bioethanol is produced through a process of pretreatment, hydrolysis, and fermentation [36-39]. The bioethanol production process is shown in Figure 1. 


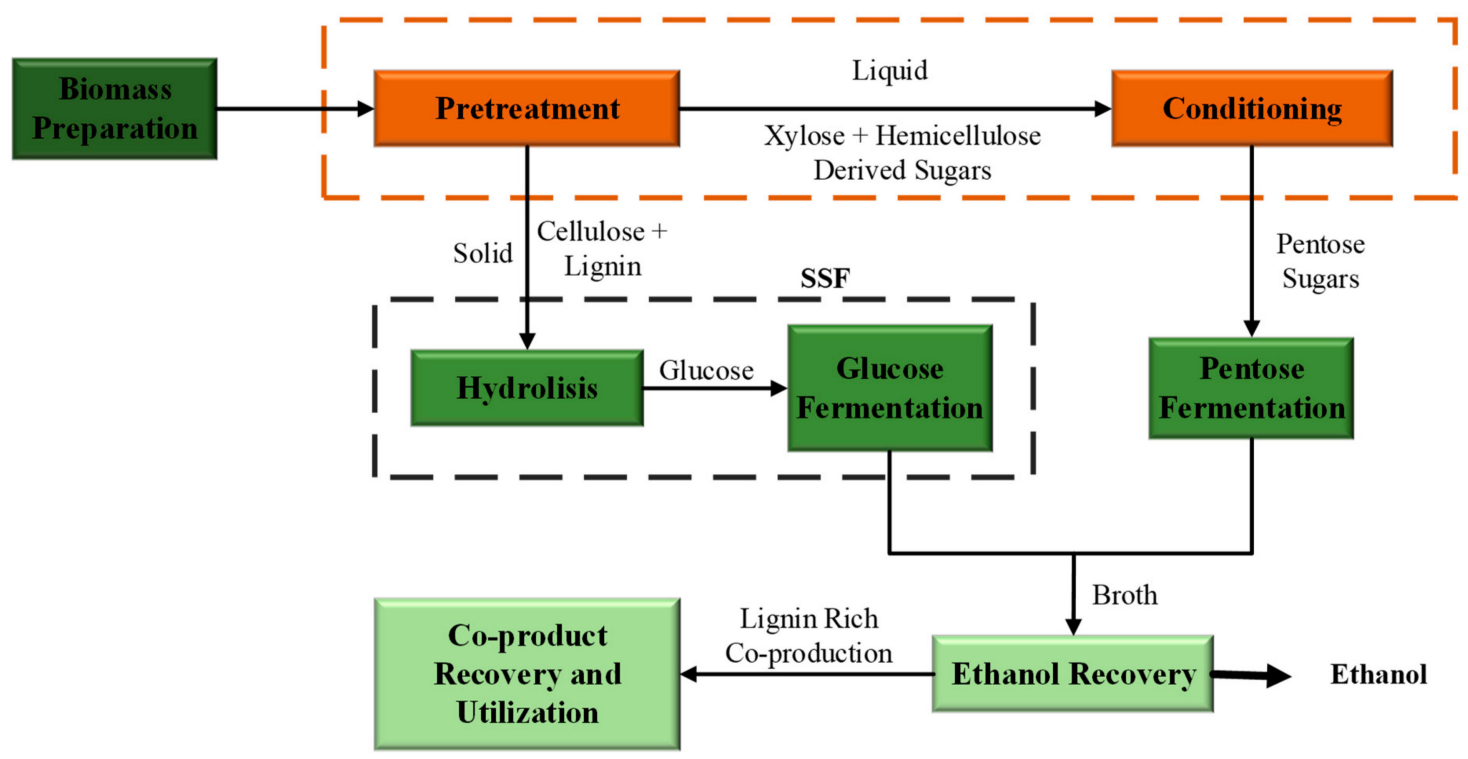

Figure 1. Schematic of the steps involved in conversion of lignocellulose biomass to ethanol [40].

\subsection{Pretreatment}

Pretreatment is an important step to break down the carbohydrates in which the process aim is to reduce the size of the materials used $[31,41]$ and unlock the cellulose by releasing the lignin in the cellulose [42-44]. Commonly used methods for pretreatment include physicochemical methods (ozonolysis, steam treatment, wet oxidation, and ammonia fiber explosion), chemical methods (acid hydrolysis, alkaline hydrolysis, and organic solvent treatment) [41,45-47], electrical methods (such as pulsed electric field treatment), biological methods (using bacteria or fungi producing ligninolytic enzymes), or a combination of these [32,48].

\subsection{Hydrolysis}

Hydrolysis consists of the degradation of polysaccharides in aqueous media that can be catalyzed by enzymes, acids, or bases to produce glucose [13,36,42,49-63]. The hydrolysis result will depend on the reaction of enzymes and compounds [64-67].

The hydrolysis yield is determined as the amount of extracted reducing sugars per total amount of theoretical glucose in the biomass according to the following equation $[68,69]$ :

$$
\text { Hydrolysis yield }(\%)=\frac{\text { Extracted reducing sugar }(\mathrm{g})}{\text { theoretical glucose }(\mathrm{g})} \times 100 \text {. }
$$

For a total conversion, the glucose theoretically obtained is the same as the amount of cellulose in biomass waste. Total reducing sugars are obtained using the method as follows [70]:

$$
\text { Extracted reducing sugar }(\mathrm{mg})=\text { Concentration }(\mathrm{mg} / \mathrm{mL}) \times \text { Volume }_{\text {Test }}
$$

Fermentation yield $(Y)$ is expressed as the obtained ethanol after the distillation process per the amount of extracted reducing sugars:

$$
\mathrm{Y}(\%)=\frac{\text { ethanol }(\mathrm{g})}{\text { Extracted Reducing Sugar }(\mathrm{g})} \times 100
$$


Fermentation efficiency corresponds to the ratio of the produced ethanol over the theoretically produced ethanol [71], as follows:

$$
\text { Ethanol }(\%)=\frac{\text { Ethanol }_{\text {Observed }}}{\text { Ethanol }_{\text {theor }}} \times 100
$$

The bioethanol yield can be obtained using the following equation [29]:

$$
\text { Bioethanol Yield }\left(\frac{\mathrm{g}}{\mathrm{g}}\right)=\frac{\text { Volume }_{\text {Hidrolisate }}(L) \times \text { Concentration }_{\text {bioethanol }}(\mathrm{g} / \mathrm{L})}{10 \mathrm{~g} \text { Biomass Waste }}
$$

Finally, the physical properties of the obtained residue after acid hydrolysis were tested. This analysis included moisture, calorific value, and elemental, inorganic compounds, and immediate analysis according to the standards [68].

\subsection{Fermentation}

The fermentation process consists of the conversion of glucose obtained from hydrolysis to bioethanol by microorganism media such as yeast, bacteria, and fungi [62,72,73]. Saccharomyces cerevisiae was used for fermentation assays [74-76]. This fermentation process lasts several days depending on the number of yeast cell culture starters used. The larger the number of starters, the faster the fermentation process. Besides producing ethanol, fermentation produces also other substances, including water. One measure of the quality of bioethanol is its water content. The lower the water content, the better the quality of the bioethanol $[19,77]$, (Table 1). 
Table 1. Advantages and disadvantages of methods for pretreatment lignocellulose materials.

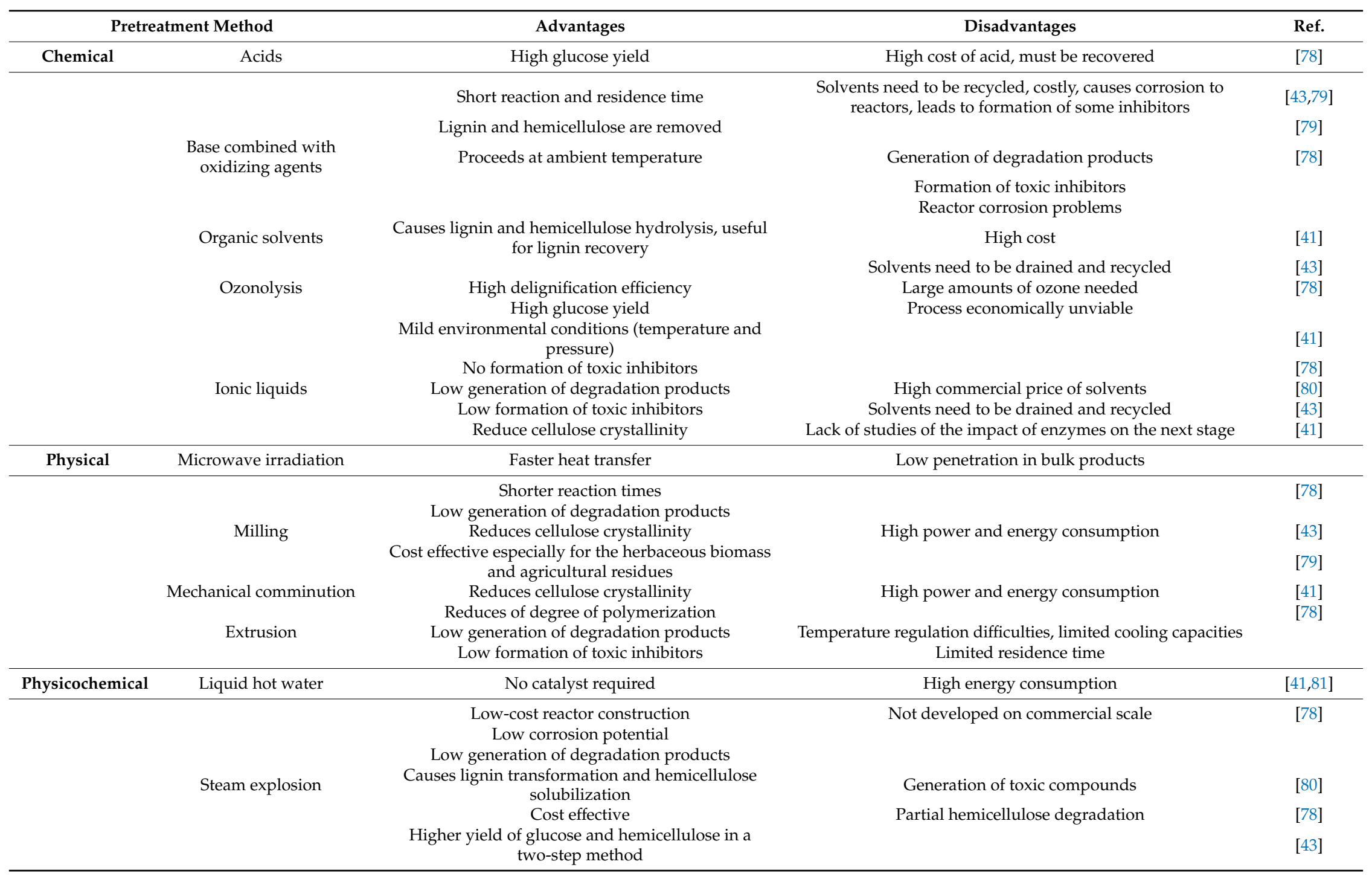


Table 1. Cont.

\begin{tabular}{|c|c|c|c|}
\hline Pretreatment Method & Advantages & Disadvantages & Ref. \\
\hline \multirow[t]{3}{*}{$\mathrm{CO}_{2}$ explosion } & Increase accessible surface area & Does not affect lignin and hemicelluloses & [43] \\
\hline & Cost effective & Very high pressure requirements & {$[33,41]$} \\
\hline & Does not generate of toxic compounds & & \\
\hline \multirow[t]{3}{*}{ Ammonia fiber explosion } & Increases accessible surface area & Not efficient for raw materials with high lignin content & [79] \\
\hline & Low formation of inhibitors & High cost of large amount of ammonia & [78] \\
\hline & & High cost of ammonia & \\
\hline \multirow[t]{3}{*}{ Soaking aqueous ammonia } & Performed at lower temperature & & [78] \\
\hline & Glycan and xylene remain in the solid & & \\
\hline & Low formation of inhibitors & & \\
\hline \multirow[t]{5}{*}{ Biological } & Degrades lignin and hemicellulose & Low rate of hydrolysis & [41] \\
\hline & Low energy consumption & & [43] \\
\hline & Low-capital cost & & \\
\hline & No chemicals requirement & & [78] \\
\hline & Mild environmental conditions & & [79] \\
\hline
\end{tabular}




\section{Wax Problems and Use of Solvents in the Oil Industry}

Most of the commercial wax inhibitors tested can reduce the deposition of paraffin with low molecular weight $\left(\leq C_{34}\right)$, but have little effect on high molecular weight paraffinic wax $\left(C_{35}-C_{44}\right)$ [82]. Wax deposition in oil production flow mainly consists of $C_{7}$ paraffin. Paraffin deposition is controlled by temperature, which is why heat application is preferable to manage the paraffin deposition $[83,84]$. When the temperature in a system decreases, paraffin in the liquid phase starts precipitating out of the solution as a solid. Wax deposition forms on the wall of the pipe where the temperature gradient is at its highest $[3,85]$. Pressure-temperature relationship of wax appearance in both reservoir fluid and stock tank oil (STO) condition is shown by Figure 2.

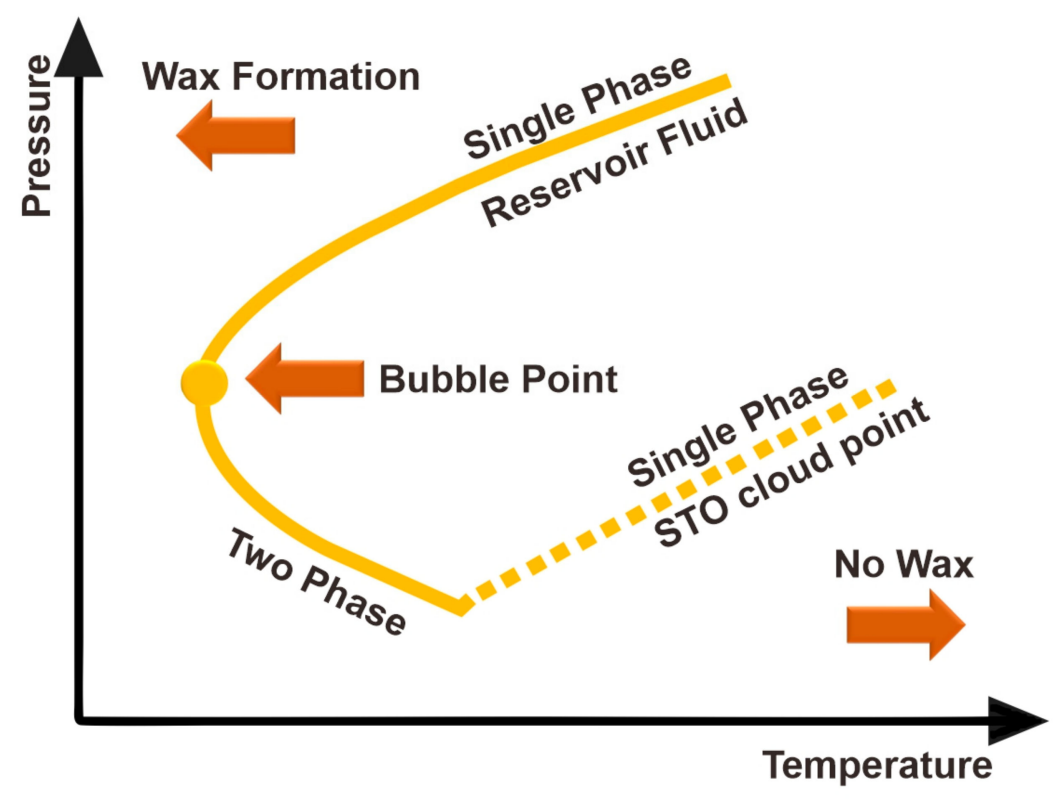

Figure 2. Pressure-temperature relationship of wax appearance in both reservoir fluid and stock tank oil (STO) condition.

The tendency and deposition rate can be adequately predicted by calculating the rate of diffusion of wax molecules onto the wall with the following equation:

$$
\frac{d m}{d t}=-\rho D_{m} A \frac{d C}{d r}
$$

where $m$ is the mass of deposit $(\mathrm{kg}), \rho$ is the density of wax $\left(\mathrm{kg} / \mathrm{m}^{3}\right), D_{m}$ is the molecular diffusion constant $\left(\mathrm{m}^{2} / \mathrm{s}\right), A$ is the deposition area $\left(\mathrm{m}^{2}\right), C$ is the concentration of wax $(\%)$, and $\mathrm{r}$ is the radial position $(\mathrm{m})[86]$.

The radial concentration gradient can be easily calculated if it is broken down into two components by applying the chain rule as shown in the following equation:

$$
\frac{d m}{d t}=-\rho D_{m} A \frac{\partial C}{\partial T} \frac{d T}{d r}
$$

where $T$ is temperature. The concentration gradient can be calculated from the wax concentration predicted by the thermodynamic model for the temperature range $[3,86]$.

Additional chemicals considerably affect the process of paraffin wax deposition, where measurements show that wax deposition is rather high for all crude oil [87]. No correlation exists between the temperature and levels of total wax of crude oil [4]. The deposition of paraffin or wax can be called a depositor of carbonaceous material, which is insoluble or dispersed by crude oil under normal conditions $[88,89]$. 
The effectiveness of the inhibitor must be tested for each application. Tests must be conducted under all possible operating conditions. Chemical inhibitors for prevention of wax include:

(1) Thermodynamic wax inhibitor (TWI)—pressing cloud point, reducing viscosity and pour point, requires a high volume;

(2) Depressant/pour point-modifies the wax crystal structure, reduces viscosity, and produces stress, but does not reduce the rate of wax deposition;

(3) Dispersants/surfactants coat wax crystals to prevent wax growth and change the wetting characteristics to minimize wax adhesion to the pipe wall or other crystals $[3,90]$.

Wax characteristics are outlined in Table 2.

Table 2. Physical characteristic carbon distribution analysis and molecular type composition of slack wax crudes [91].

\begin{tabular}{|c|c|c|c|}
\hline \multirow{2}{*}{ Characteristic } & \multicolumn{3}{|c|}{ Slack Waxes } \\
\hline & Light & Middle & Heavy \\
\hline Congealing point, ${ }^{\circ} \mathrm{C}$ & 48 & 59 & 62.5 \\
\hline Kinematic viscosity, $98.9^{\circ} \mathrm{C}$ & 3.04 & 4.30 & 6.00 \\
\hline Refractive index, $98.9{ }^{\circ} \mathrm{C}$ & 1.4224 & 1.4270 & 1.4402 \\
\hline Density, $70^{\circ} \mathrm{C}$ & 0.7920 & 0.8035 & 0.8107 \\
\hline Mean molecular weight & 384 & 446 & 477 \\
\hline Oil content, wt.\% & 5.32 & 6.23 & 23.05 \\
\hline Cone penetration, $25^{\circ} \mathrm{C}$ & 17 & 13 & 28 \\
\hline Needle penetration, ${ }^{\circ} \mathrm{C}$ & 43 & 40 & 59 \\
\hline Sulfur content, wt.\% & 0.09 & 0.10 & 0.22 \\
\hline Color (ASTM D-1500) & 1.0 & 1.5 & 3.0 \\
\hline \multicolumn{4}{|c|}{ Carbon Distribution Analysis } \\
\hline$\% \mathrm{C}_{\mathrm{A}}$ & 5.93 & 8.41 & 10.46 \\
\hline$\% \mathrm{C}_{\mathrm{N}}$ & 12.85 & 14.20 & 29.44 \\
\hline$\% C_{R}$ & 18.78 & 22.61 & 39.90 \\
\hline$\% \mathrm{C}_{\mathrm{P}}$ & 81.22 & 77.39 & 60.10 \\
\hline \multicolumn{4}{|c|}{ Molecular Type Composition } \\
\hline Total saturates, wt.\% & 97.63 & 96.97 & 86.18 \\
\hline n-paraffin content, wt. $\%$ & 74.71 & 62.89 & 35.07 \\
\hline Iso- and cyclo-paraffin content, wt. $\%$ & 22.92 & 34.08 & 51.11 \\
\hline Total aromatics, wt.\% & 2.37 & 3.03 & 13.82 \\
\hline Mono-aromatics, wt. $\%$ & 2.37 & 3.03 & 11.52 \\
\hline di-aromatics, wt.\% & & - & 2.30 \\
\hline \multicolumn{4}{|c|}{ 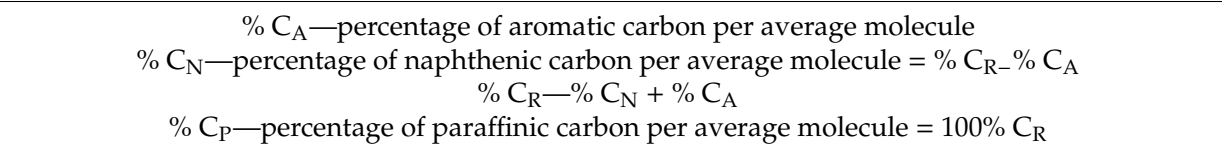 } \\
\hline
\end{tabular}

\subsection{Pour Point Depressants (PPDs)}

Pour point depressants (PPDs) are a solution in heavy or extra-heavy crude oils where the main problem is flowability, especially from offshore to ground facilities [92,93]. A crystal candle modifier, also called a PPD, is a chemical that determines the solubility of wax, adsorption, and nucleation. The modification of wax crystallization may help depress the crude oil's pour point, viscosity, and yield stress appreciably [94].

Many polymers have been used as pouring depressants. In heavy waxed oils, high-branched poly- $\alpha$-olefins, long-chain fatty acid amides, poly-n-alkyl, acrylates, methacrylate copolymers [95], alkyl ester copolymer carboxylic acids, unsaturated $\alpha$-olefin, ethylene-vinyl fatty acid esters, vinyl acetate- $\alpha$-olefins, and maleic anhydride copolymers are used. A number of patents have been generated for these polymers [92].

Examining the effect any different PPDs on the viscosity, pouring point, and temperature of the candle selection proved that PPD substances are able to reduce the wax crystals, changing the growth 
characteristics and surface of the crystal at metal surfaces that are attached like pipe walls [96], as shown in Figure 3. Studies were able to reduce crude oil from $1000 \mathrm{cP}$ to $10 \mathrm{cP}$ at $10^{\circ} \mathrm{C}-20^{\circ} \mathrm{C}$ in all of these additives, which increased the flow of crude oil. The following effect on the viscosity of crude oil was successfully modeled by regulating lower melting temperatures for wax molecules in the range of $C_{21}$ to $C_{45}$ in the presence of additives that increase flow [95].

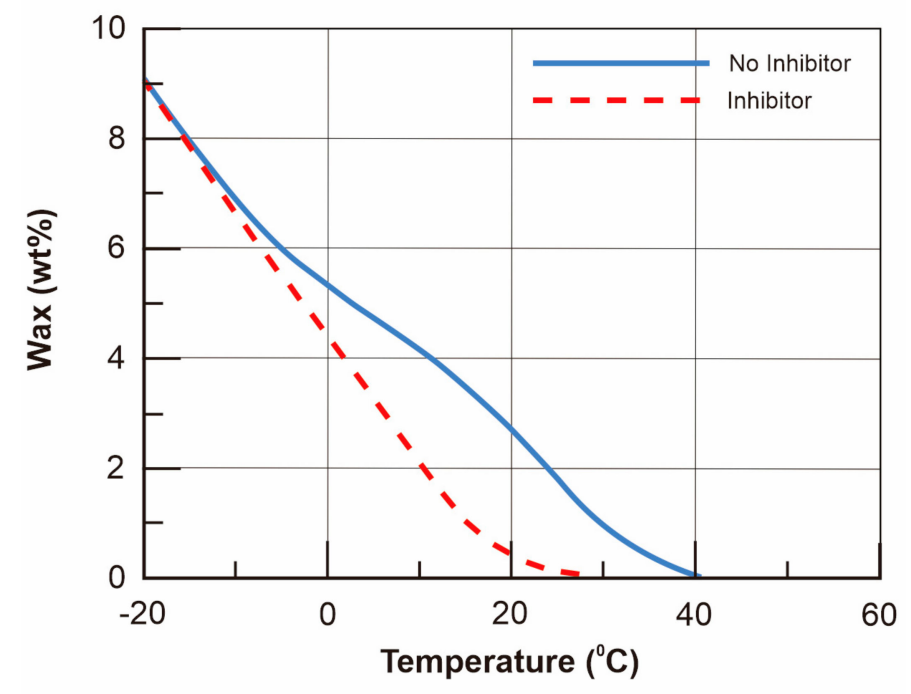

Figure 3. Precipitated weight of paraffin from the oil with (dashed line) and without (solid line) inhibitor [95].

Several studies have been conducted in Mexico to test the rheological properties of light and heavy oils by measuring pouring depressant performance using a combination of vinyl acetate, styrene, and n-butyl acrylate, and viscosity was reduced at $25^{\circ} \mathrm{C}$ and $50{ }^{\circ} \mathrm{C}$ [97]. In other studies, the viscosity in heavy crude oil dropped at $25^{\circ} \mathrm{C}$ and in light crude oil at $313 \mathrm{~K}$ due to the depressant pour point [92].

Figure 4 shows the effect of concentration on the depressant pour point. The pour point can be reduced at $11^{\circ} \mathrm{C}$ and a dose of $400 \mathrm{ppm}$. At doses above $400 \mathrm{ppm}$, no further reduction in pour point occurs, which causes it to be uneconomical [94].

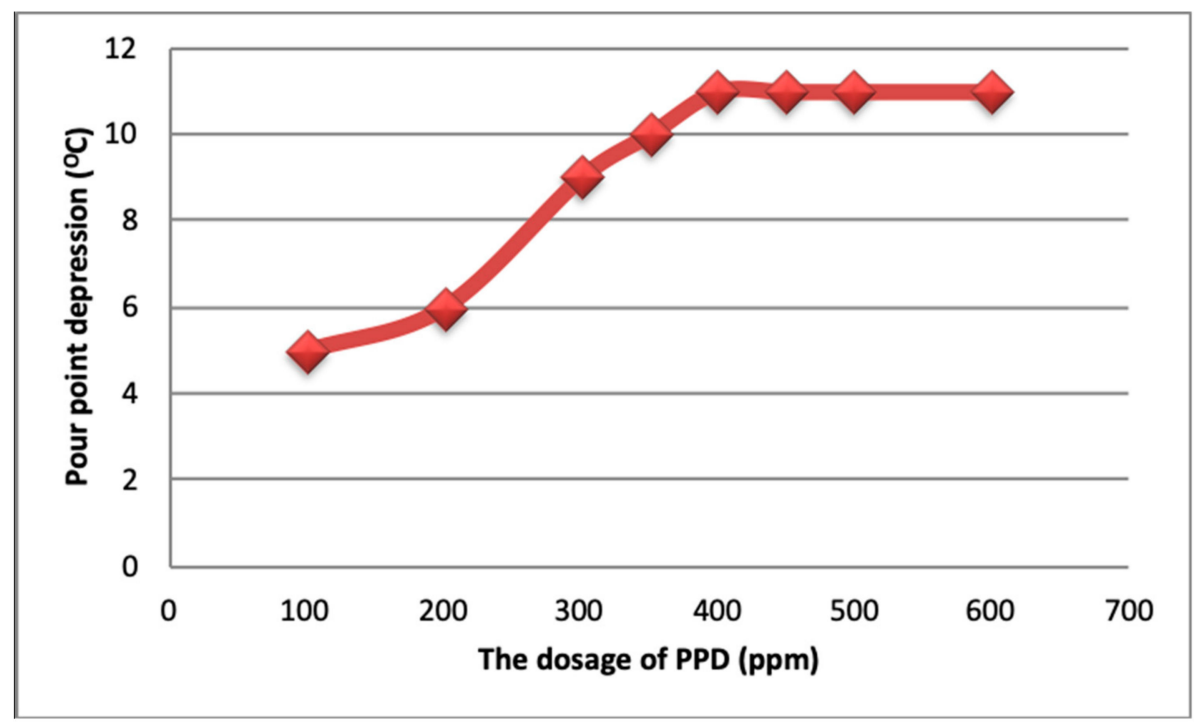

Figure 4. Effects of pour point depressant (PPD) dosages on pour points. 
The pour point of pure crude oil is calculated by the following equation:

$$
\text { Pour point reduction }(\Delta \mathrm{P})=\mathrm{PP}_{\text {pure }}-\mathrm{PP}_{\text {additive }}
$$

where $\mathrm{PP}_{\text {pure }}$ is the pour point of the pure crude oil and $\mathrm{PP}_{\text {additive }}$ is the pour point of the crude oil containing additives [98].

\subsection{Rheological Studies}

The depressant pour point mixed into crude oil at $400 \mathrm{ppm}$ is depicted in Figure 5. At temperatures above $55^{\circ} \mathrm{C}$, the viscosity of crude oil decreases and remains constant at subsequent temperatures [99], meaning that at this temperature, the crude oil flow benefits because it can flow without depressant pour points $[100,101]$. When the temperature decreases, the viscosity of crude oil increases, thereby increasing the viscosity of the oil, which is then accompanied by deposition [102,103]. Then, at temperatures below $50{ }^{\circ} \mathrm{C}$, the wax appearance temperature (WAT) is higher without the addition of pour point depressant [104]. The addition of pour point depressant was proven to reduce the viscosity of crude oil so that it can increase the flow of low-temperature crude oil [105].

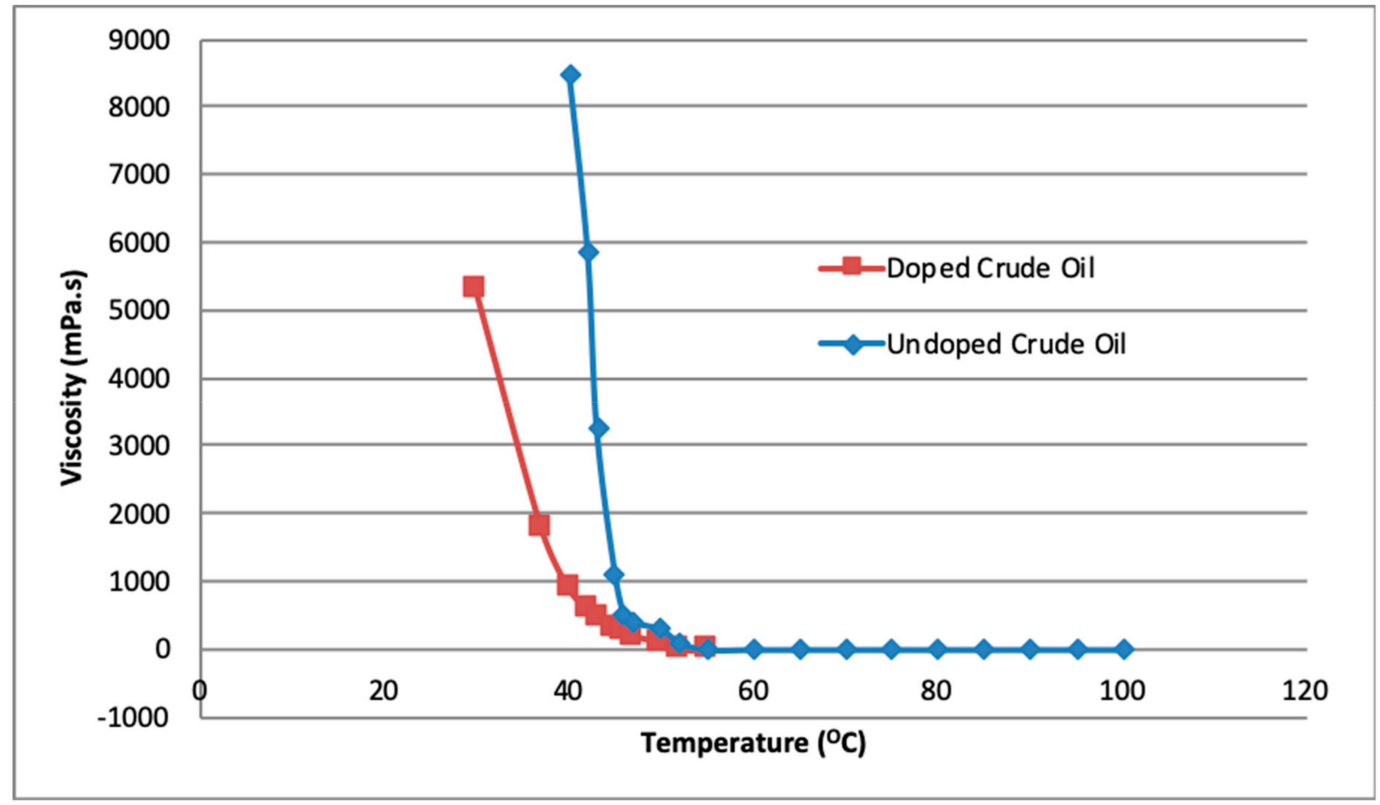

Figure 5. Comparison of wax appearance temperature with doped-undoped PPD to crude oil.

\subsection{Evaluation of Paraffin Inhibition Efficiency}

WAT Determination (ASTM Standard D5773-04, 2005)

WAT is also called the cloud point $[7,106]$. Lately, some researchers have shown the advantage of calculating wax disappearance temperature (WDT) compared to WAT. WDT is the temperature at which the last wax crystal melts. The WDT is thermodynamically more precise because crystallization requires some saturation [107]. The efficiency of paraffin inhibition (total PIE) for total wax deposition can be calculated as [88]:

$$
\operatorname{PIE}_{\text {total }}(\%)=\frac{W_{n(\mathrm{C} 11-\mathrm{C} 44)}-W_{i(\mathrm{C} 11-\mathrm{C} 44)}}{W_{n(\mathrm{C} 11-\mathrm{C} 44)}} \times 100
$$

where $W_{n(\mathrm{C} 11-\mathrm{C} 44)}$ is the total amount of paraffin deposits without inhibitors $(\mathrm{mg})$ and $\left.W_{i(\mathrm{C} 11-\mathrm{C} 44)}\right)$ is the amount of paraffin deposit with added inhibitors (mg) [4,82]. The effects of commercial wax inhibitors on $\triangle \mathrm{WAT}$ and inhibitor efficiency in wax deposition is shown by Table 3 below. 
Table 3. Effects of commercial wax inhibitors (200 ppm) on $\triangle \mathrm{WAT}$, and inhibitor efficiency in paraffin deposition [82].

\begin{tabular}{cccccc}
\hline Inhibitor & Chemical Name & $\Delta$ WAT $\left({ }^{\circ} \mathbf{C}\right)$ & PIE $_{\text {light }}(\mathbf{\%})$ & PIE $_{\text {heavy }}(\mathbf{\%})$ & PIE $_{\text {ltotal }}(\mathbf{\%})$ \\
\hline A & Poly alkyl enamine & -2.7 & 71 & 13 & 52 \\
B & Proprietary & -3.3 & 87 & 75 & 83 \\
C & Polyolefin amide alkene amine & -0.1 & 18 & -9 & 9 \\
D & Polyolefin amide alkene amine & -0.2 & 33 & 3 & 23 \\
E & Poly acrylate & 0.0 & 42 & 28 & 37 \\
F & Poly alkyl acrylate & -3.4 & 72 & 18 & 54 \\
G & Olefin amide copolymer & -1.7 & 55 & -3 & 36 \\
H & Proprietary & -4.2 & 73 & 29 & 58 \\
\hline
\end{tabular}

\section{Discussion}

Solvent treatments of wax deposition are often the most successful remediation methods but are also the most costly. Therefore, solvent remediation methods are usually reserved for applications where hot oil or hot water methods have shown little success. When solvents contact the wax, the deposits are dissolved until the solvents are saturated. If they are not removed after saturation is reached, the waxes may precipitate, resulting in a situation more severe than prior to treatment [3].

\subsection{Production of Solvents for the Oil Industry}

The process of producing a solvent from biomass waste certainly has the potential for development, especially with the increasing amount of waste produced by people today. Very little of that waste can be recycled back into a valuable product, which is a complex problem for the industrial world that must be addressed. This is especially true in the oil industry, as the chemical treatment needed to overcome this problem is enabling the development of the world of industry by optimizing petroleum production [108].

\subsection{Solvent Application in the Oil Industry}

One important challenge in crude oil production and fuel handling is the risk of wax deposition. This deposition is of particular concern in the production of crude oil from deep-water fields where the liquid produced can cool to near the surrounding water temperature, which is $4{ }^{\circ} \mathrm{C}$ or less. The paraffin deposits that can occur in these long transportation routes can endanger these projects due to partial or even complete blockages of these pipes [82,89].

Paraffin hydrocarbon liquids, including crude oil and condensate, form a paraffin solid phase when the temperature drops below the liquid cloud point [4]. Cast points are indicators of temperature where oil will solidify into a gel. At the pour point, the fluid still flows under gravity; at the next lower measurement temperature (lower than $3{ }^{\circ} \mathrm{C}$ ), the fluid has already formed a gel and does not flow. In the ambient temperature, where the fluid is at or below the temperature of the pour point, special pouring strategies are needed to maintain fluid flow capability. So, the ambient temperature condition can be analyzed in general so that the analysis is conservative. The extreme 100-year minimum seabed temperature is used along the pipeline route [3].

\section{Conclusions}

In this study, we examined the feasibility of bio-solvent application to the inhibition of the deposition of wax that forms in oil production facilities. Generally, we found that the bioethanol production process, used to create a solvent, shows potential, especially bio-solvents which are created from biomass in the surrounding environment. The ability of bioethanol to act as a suitable solvent to prevent the deposition of paraffin wax must be determined. This study has been one of the first attempts to thoroughly assess this wax problem. The process of assessment for a wax problem in an oilfield can be summarized as follows: obtain a good sample; determine the cloud point or WAT based on solid-liquid equilibrium; determine the rheology including the viscosity, pour point, and 
gel strength; the crude oil composition must be quantified, including standard oil composition; wax deposition rates must be identified, including flow loop, wax melting point, interfacial tension; and the use of wax inhibitors from biomass or organic waste should be considered. Using a wax paraffin solvent produced from biomass is an intriguing challenge that could be explored in further research.

Author Contributions: Conceptualization, M.K.A., M.A., and F.H.; writing-original draft preparation, M.K.A.; writing-review and editing, M.K.A., and F.H.; visualization, M.K.A.; supervision, M.A.; project administration, M.A., F.K.C., and H.F.M.Z.; funding acquisition, M.A., F.K.C., and H.F.M.Z.

Funding: This research was funded by Joint Research Funding UIR-UTP, grant number 469/KONTRAK/LPPM-UIR/9-2018 and The APC was funded by Universitas Islam Riau, Universiti Teknologi Petronas, and PT. Chevron Pacific Indonesia.

Acknowledgments: This research was supported by the cooperation of the Universitas Islam Riau and the Universiti Teknologi Petronas and thanks are given for funding.

Conflicts of Interest: The authors declare no conflicts of interest.

\section{Nomenclature}

$\begin{array}{ll}\text { TWI } & \text { Thermodynamic wax inhibitor } \\ \text { WAT } & \text { Wax appearance temperature } \\ \text { WDT } & \text { Wax disappearance temperature } \\ \text { WTE } & \text { Waste to energy } \\ \text { PIE } & \text { Paraffin inhibition efficiency }\end{array}$

\section{References}

1. Tukenov, D. Technology update: Nanochemistry drives new method for removal and control of wax. J. Pet. Technol. 2014, 66, 30-33. [CrossRef]

2. Taraneh, J.B.; Rahmatollah, G.; Hassan, A.; Alireza, D. Effect of wax inhibitors on pour point and rheological properties of Iranian waxy crude oil. Fuel Process. Technol. 2008, 89, 973-977. [CrossRef]

3. Bai, Y.; Bai, Q. Wax and asphaltenes. In Subsea Engineering Handbook; Gulf Professional Publishing: Houston, TX, USA, 2018; pp. 435-453. ISBN 978-0-12-812622-6.

4. Bello, O.; Fasesan, S.; Teodoriu, C.; Reinicke, K. An evaluation of the performance of selected wax inhibitors on paraffin deposition of Nigerian crude oils. Pet. Sci. Technol. 2006, 24, 195-206. [CrossRef]

5. Yao, B.; Li, C.; Yang, F.; Zhang, Y.; Xiao, Z.; Sun, G. Structural properties of gelled Changqing waxy crude oil benefitted with nanocomposite pour point depressant. Fuel 2016, 184, 544-554. [CrossRef]

6. Admiral, A.; Abdullah, M.K.; Ariffin, A. Evaluation of emulsified acrylate polymer and its pour point depressant performance. Procedia Chem. 2016, 19, 319-326. [CrossRef]

7. Merino-Garcia, D.; Correra, S. Cold flow: A review of a technology to avoid wax deposition. Pet. Sci. Technol. 2008, 26, 446-459. [CrossRef]

8. Xiao, Y.; Wu, B.; Fu, X.; Wang, R.; Lei, J. Preparation of biodegradable microcapsules through an organic solvent-free interfacial polymerization method. Polym. Adv. Technol. 2019, 30, 483-488. [CrossRef]

9. Yuliusman; Nasruddin; Afdhol, M.K.; Haris, F.; Amiliana, R.A.; Hanafi, A.; Ramadhan, I.T. Production of activated carbon from coffee grounds using chemical and physical activation method. Adv. Sci. Lett. 2017, 23, 5751-5755. [CrossRef]

10. Yuliusman; Afdhol, M.K.; Sanal, A.; Nasruddin. CFD modelling of adsorption behaviour in AGN tank with polyethylene terephthalate plastic waste based activated carbon. IOP Conf. Ser. Mater. Sci. Eng. 2018, 316, 012015. [CrossRef]

11. Shuai, L.; Luterbacher, J. Organic solvent effects in biomass conversion reactions. ChemSusChem 2016, 9, 133-155. [CrossRef]

12. Zhang, C.; Chen, H.; Pang, S.; Su, C.; Lv, M.; An, N.; Wang, K.; Cai, D.; Qin, P. Importance of redefinition of corn stover harvest time to enhancing non-food bio-ethanol production. Renew. Energy 2020, 146, 1444-1450. [CrossRef]

13. Alencar, B.R.A.; Dutra, E.D.; Sampaio, E.V.d.S.B.; Menezes, R.S.C.; Morais, M.A. Enzymatic hydrolysis of cactus pear varieties with high solids loading for bioethanol production. Bioresour. Technol. 2018, 250, 273-280. [CrossRef] [PubMed] 
14. Pérez-Sánchez, M.; Sandoval, M.; Hernáiz, M.J. Bio-solvents change regioselectivity in the synthesis of disaccharides using Biolacta $\beta$-galactosidase. Tetrahedron 2012, 68, 2141-2145. [CrossRef]

15. Tobiszewski, M. Analytical chemistry with biosolvents. Anal. Bioanal. Chem. 2019, 411, 4359-4364. [CrossRef]

16. Bergez-Lacoste, M.; Thiebaud-Roux, S.; De Caro, P.; Fabre, J.-F.; Gerbaud, V.; Mouloungui, Z. From chemical platform molecules to new biosolvents: Design engineering as a substitution methodology. Biofuels Bioprod. Biorefin. 2014, 8, 438-451. [CrossRef]

17. Katrib, F.A.; Chambat, G.; Joseleau, J.-P. Organic solvent pretreatment to enhance enzymic saccharification of straw. J. Sci. Food Agric. 1988, 43, 309-317. [CrossRef]

18. Bar, R.; Gainer, J.L. Acid fermentation in water-organic solvent two-liquid phase systems. Biotechnol. Prog. 1987, 3, 109-114. [CrossRef]

19. Rocha-Meneses, L.; Raud, M.; Orupõld, K.; Kikas, T. Potential of bioethanol production waste for methane recovery. Energy 2019, 133-139. [CrossRef]

20. Biswas, B.; Kumar, J.; Bhaskar, T. Advanced hydrothermal liquefaction of biomass for bio-oil production. In Biofuels: Alternative Feedstocks and Conversion Processes for the Production of Liquid and Gaseous Biofuels, 2nd ed.; Pandey, A., Larroche, C., Dussap, C.-G., Gnansounou, E., Khanal, S.K., Ricke, S., Eds.; Academic Press: Cambridge, MA, USA, 2019; pp. 245-266. ISBN 978-0-12-816856-1.

21. Breeden, S.W.; Clark, J.H.; Macquarrie, D.J.; Sherwood, J. Green solvents. In Green Techniques for Organic Synthesis and Medicinal Chemistry; Zhang, W., Cue, B.W., Jr., Eds.; John Wiley \& Sons, Ltd.: Hoboken, NJ, USA, 2012; pp. 241-261.

22. Soccol, C.R.; de Souza Vandenberghe, L.P.; Medeiros, A.B.P.; Karp, S.G.; Buckeridge, M.; Ramos, L.P.; Pitarelo, A.P.; Ferreira-Leitão, V.; Gottschalk, L.M.F.; Ferrara, M.A.; et al. Bioethanol from lignocelluloses: Status and perspectives in Brazil. Bioresour. Technol. 2010, 101, 4820-4825. [CrossRef]

23. Martín, M.; Grossmann, I.E. Superstructure optimization of Lignocellulosic Bioethanol plants. In 20th European Symposium on Computer Aided Process Engineering; Computer Aided Chemical Engineering Volume 28; Pierucci, S., Ferraris, G.B., Eds.; Elsevier: Amsterdam, The Netherlands, 2010; pp. 943-948. ISBN 1570-7946.

24. Camargos, C.H.M.; Silva, R.A.P.; Csordas, Y.; Silva, L.L.; Rezende, C.A. Experimentally designed corn biomass fractionation to obtain lignin nanoparticles and fermentable sugars. Ind. Crop. Prod. 2019, 140, 111649. [CrossRef]

25. Abaide, E.R.; Dotto, G.L.; Tres, M.V.; Zabot, G.L.; Mazutti, M.A. Adsorption of 2-nitrophenol using rice straw and rice husks hydrolyzed by subcritical water. Bioresour. Technol. 2019, 284, 25-35. [CrossRef]

26. Romo, J.E.; Bollar, N.V.; Zimmermann, C.J.; Wettstein, S.G. Conversion of sugars and biomass to furans using heterogeneous catalysts in biphasic solvent systems. ChemCatChem 2018, 10, 4805-4816. [CrossRef]

27. Zhang, Y.; Liu, Z.; Liu, H.; Hui, L.; Wang, H.; Liu, H. Characterization of liquefied products from corn stalk and its biomass components by polyhydric alcohols with phosphoric acid. Carbohydr. Polym. 2019, 215, 170-178. [CrossRef]

28. Cucchiella, F.; D'Adamo, I.; Gastaldi, M. Sustainable waste management: Waste to energy plant as an alternative to landfill. Energy Convers. Manag. 2017, 131, 18-31. [CrossRef]

29. Yuliusman; Nasruddin; Afdhol, M.K.; Amiliana, R.A.; Hanafi, A. Preparation of activated carbon from palm shells using $\mathrm{KOH}$ and $\mathrm{ZnCl}_{2}$ as the activating agent. IOP Conf. Ser. Mater. Sci. Eng. 2017, 180, 012282. [CrossRef]

30. Yuliusman; Afdhol, M.K.; Sanal, A. Carbon monoxide and methane adsorption of crude oil refinery using activated carbon from palm shells as biosorbent. IOP Conf. Ser. Mater. Sci. Eng. 2018, 316, 012016. [CrossRef]

31. Tsegaye, B.; Balomajumder, C.; Roy, P. Optimization of microwave and $\mathrm{NaOH}$ pretreatments of wheat straw for enhancing biofuel yield. Energy Convers. Manag. 2019, 186, 82-92. [CrossRef]

32. Nikolić, S.; Mojović, L.; Rakin, M.; Pejin, D. Bioethanol production from corn meal by simultaneous enzymatic saccharification and fermentation with immobilized cells of Saccharomyces cerevisiae var. ellipsoideus. Fuel 2009, 88, 1602-1607. [CrossRef]

33. Balat, M.; Balat, H.; Öz, C. Progress in bioethanol processing. Prog. Energy Combust. Sci. 2008, 34, 551-573. [CrossRef]

34. Zhao, Y.; Damgaard, A.; Christensen, T.H. Bioethanol from corn stover-A review and technical assessment of alternative biotechnologies. Prog. Energy Combust. Sci. 2018, 67, 275-291. [CrossRef] 
35. Mabee, W.E.; Saddler, J.N. Bioethanol from lignocellulosics: Status and perspectives in Canada. Bioresour. Technol. 2010, 101, 4806-4813. [CrossRef]

36. Nikolić, S.; Mojović, L.; Pejin, D.; Rakin, M.; Vukašinović, M. Production of bioethanol from corn meal hydrolyzates by free and immobilized cells of Saccharomyces cerevisiae var. ellipsoideus. Biomass Bioenergy 2010, 34, 1449-1456. [CrossRef]

37. Saha, K.; Maheswari, U.R.; Sikder, J.; Chakraborty, S.; da Silva, S.S.; dos Santos, J.C. Membranes as a tool to support biorefineries: Applications in enzymatic hydrolysis, fermentation and dehydration for bioethanol production. Renew. Sustain. Energy Rev. 2017, 74, 873-890. [CrossRef]

38. Thangavelu, S.K.; Rajkumar, T.; Pandi, D.K.; Ahmed, A.S.; Ani, F.N. Microwave assisted acid hydrolysis for bioethanol fuel production from sago pith waste. Waste Manag. 2019, 86, 80-86. [CrossRef]

39. Gnansounou, E. Production and use of lignocellulosic bioethanol in Europe: Current situation and perspectives. Bioresour. Technol. 2010, 101, 4842-4850. [CrossRef]

40. Kumar, D.; Singh, V. Bioethanol production from corn. In Corn, 3rd ed.; Chemistry and Technology; Serna-Saldiva, S.O., Ed.; Woodhead Publishing: Sawston, UK, 2019; pp. 615-631.

41. Aditiya, H.B.; Mahlia, T.M.I.; Chong, W.T.; Nur, H.; Sebayang, A.H. Second generation bioethanol production: A critical review. Renew. Sustain. Energy Rev. 2016, 66, 631-653. [CrossRef]

42. Chen, H.; Fu, X. Industrial technologies for bioethanol production from lignocellulosic biomass. Renew. Sustain. Energy Rev. 2016, 57, 468-478. [CrossRef]

43. Bhatt, S.M. Shilpa Lignocellulosic feedstock conversion, inhibitor detoxification and cellulosic hydrolysis-A review. Biofuels 2014, 5, 633-649. [CrossRef]

44. Wang, X.; Xie, X.; Sun, J.; Liao, W. Effects of liquefaction parameters of cellulose in supercritical solvents of methanol, ethanol and acetone on products yield and compositions. Bioresour. Technol. 2019, 275, 123-129. [CrossRef]

45. Sarkar, N.; Ghosh, S.K.; Bannerjee, S.; Aikat, K. Bioethanol production from agricultural wastes: An overview. Renew. Energy 2012, 37, 19-27. [CrossRef]

46. Tiryaki, O.N.; Irmak, S.; Ramchandran, D.; Subbiah, J.; Morton, M. Utilization of excess corn kernels for hydrogen gas biofuel production. Int. J. Hydrog. Energy 2019, 44, 29956-29963. [CrossRef]

47. Zhao, L.; Ou, X.; Chang, S. Life-cycle greenhouse gas emission and energy use of bioethanol produced from corn stover in China: Current perspectives and future prospectives. Energy 2016, 115, 303-313. [CrossRef]

48. Gomes, J.; Batra, J.; Chopda, V.R.; Kathiresan, P.; Rathore, A.S. Monitoring and control of bioethanol production from lignocellulosic biomass. In Waste Biorefinery: Potential and Perspectives; Bhaskar, T., Pandey, A., Mohan, S.V., Lee, D.-J., Khanal, S.K., Eds.; Elsevier: Amsterdam, The Netherlands, 2018; pp. 727-749.

49. Pino, M.S.; Rodríguez-Jasso, R.M.; Michelin, M.; Flores-Gallegos, A.C.; Morales-Rodriguez, R.; Teixeira, J.A.; Ruiz, H.A. Bioreactor design for enzymatic hydrolysis of biomass under the biorefinery concept. Chem. Eng. J. 2018, 347, 119-136. [CrossRef]

50. Li, X.; Kim, T.H.; Nghiem, N.P. Bioethanol production from corn stover using aqueous ammonia pretreatment and two-phase simultaneous saccharification and fermentation (TPSSF). Bioresour. Technol. 2010, 101, 5910-5916. [CrossRef]

51. Talebnia, F.; Karakashev, D.; Angelidaki, I. Production of bioethanol from wheat straw: An overview on pretreatment, hydrolysis and fermentation. Bioresour. Technol. 2010, 101, 4744-4753. [CrossRef]

52. Nandal, P.; Sharma, S.; Arora, A. Bioprospecting non-conventional yeasts for ethanol production from rice straw hydrolysate and their inhibitor tolerance. Renew. Energy 2020, 147, 1694-1703. [CrossRef]

53. Xu, Y.; Zhang, X.; Yan, X.-H.; Zhang, J.-L.; Wang, L.-Y.; Xue, H.; Jiang, G.-C.; Ma, X.-T.; Liu, X.-J. Characterization, hypolipidemic and antioxidant activities of degraded polysaccharides from Ganoderma lucidum. Int. J. Biol. Macromol. 2019, 135, 706-716. [CrossRef]

54. Zou, W.; Li, J.; Vinogradov, E.; Cox, A. Removal of cell wall polysaccharide in pneumococcal capsular polysaccharides by selective degradation via deamination. Carbohydr. Polym. 2019, 218, 199-207. [CrossRef]

55. Xu, Y.; Niu, X.; Liu, N.; Gao, Y.; Wang, L.; Xu, G.; Li, X.; Yang, Y. Characterization, antioxidant and hypoglycemic activities of degraded polysaccharides from blackcurrant (Ribes nigrum L.) fruits. Food Chem. 2018, 243, 26-35. [CrossRef] 
56. Fan, X.; Jiang, W.; Gong, H.; Yang, Y.; Zhang, A.; Liu, H.; Cao, J.; Guo, F.; Cui, K. Cell wall polysaccharides degradation and ultrastructure modification of apricot during storage at a near freezing temperature. Food Chem. 2019, 300, 125194. [CrossRef]

57. Zhan, P.; Tang, K.; Chen, X.; Yu, L. Complete genome sequence of Maribacter sp. T28, a polysaccharide-degrading marine flavobacteria. J. Biotechnol. 2017, 259, 1-5. [CrossRef] [PubMed]

58. Lu, X.; Li, N.; Qiao, X.; Qiu, Z.; Liu, P. Effects of thermal treatment on polysaccharide degradation during black garlic processing. LWT 2018, 95, 223-229. [CrossRef]

59. Shao, L.-L.; Xu, J.; Shi, M.-J.; Wang, X.-L.; Li, Y.-T.; Kong, L.-M.; Hider, R.C.; Zhou, T. Preparation, antioxidant and antimicrobial evaluation of hydroxamated degraded polysaccharides from Enteromorpha prolifera. Food Chem. 2017, 237, 481-487. [CrossRef] [PubMed]

60. Hegde, S.; Lodge, J.S.; Trabold, T.A. Characteristics of food processing wastes and their use in sustainable alcohol production. Renew. Sustain. Energy Rev. 2018, 81, 510-523. [CrossRef]

61. Afdhol, M.K.; Lubis, H.Z.; Siregar, C.P. Bioethanol production from tea waste as a basic ingredient in renewable energy sources. J. Earth Energy Eng. 2019, 8, 21. [CrossRef]

62. Puspawati, S.; Wagiman; Ainuri, M.; Nugraha, D.A.; Haslianti. The production of bioethanol fermentation substrate from Eucheuma cottonii seaweed through hydrolysis by cellulose enzyme. Agric. Agric. Sci. Procedia 2015, 3, 200-205. [CrossRef]

63. Yang, J.; Zeng, J.; Wen, L.; Zhu, H.; Jiang, Y.; John, A.; Yu, L.; Yang, B. Effect of morin on the degradation of water-soluble polysaccharides in banana during softening. Food Chem. 2019, 287, 346-353. [CrossRef]

64. Phwan, C.K.; Ong, H.C.; Chen, W.H.; Ling, T.C.; Ng, E.P.; Show, P.L. Overview: Comparison of pretreatment technologies and fermentation processes of bioethanol from microalgae. Energy Convers. Manag. 2018, 173, 81-94. [CrossRef]

65. Conde-Mejía, C.; Jiménez-Gutiérrez, A.; Gómez-Castro, F.I. Purification of bioethanol from a fermentation process: Alternatives for dehydration. In Computer Aided Chemical Engineering; Elsevier B.V.: Amsterdam, The Netherlands, 2016; Volume 38, pp. 373-378. ISBN 9780444634283.

66. Fitria; Ruan, H.; Fransen, S.C.; Carter, A.H.; Tao, H.; Yang, B. Selecting winter wheat straw for cellulosic ethanol production in the Pacific Northwest, U.S.A. Biomass Bioenergy 2019, 123, 59-69. [CrossRef]

67. Lin, Q.; Wang, S.; Wang, M.; Cao, R.; Zhang, R.; Zhan, R.; Wang, K. A novel glycoside hydrolase family 42 enzyme with bifunctional $\beta$-galactosidase and $\alpha$-L-arabinopyranosidase activities and its synergistic effects with cognate glycoside hydrolases in plant polysaccharides degradation. Int. J. Biol. Macromol. 2019, 140, 129-139. [CrossRef]

68. Alfonsín, V.; Maceiras, R.; Gutiérrez, C. Bioethanol production from industrial algae waste. Waste Manag. 2019, 87, 791-797. [CrossRef] [PubMed]

69. Xie, W.; Ren, Y.; Jiang, F.; Liang, J.; Du, S. Pretreatment of quinoa straw with 1-butyl-3-methylimidazolium chloride and physiochemical characterization of biomass. Renew. Energy 2020, 146, 1364-1371. [CrossRef]

70. Xu, Y.; Liu, N.; Fu, X.; Wang, L.; Yang, Y.; Ren, Y.; Liu, J.; Wang, L. Structural characteristics, biological, rheological and thermal properties of the polysaccharide and the degraded polysaccharide from raspberry fruits. Int. J. Biol. Macromol. 2019, 132, 109-118. [CrossRef] [PubMed]

71. Sayed, W.; Cabrol, A.; Abdallah, R.; Taha, S.; Amrane, A.; Djelal, H. Enhancement of ethanol production from synthetic medium model of hydrolysate of macroalgae. Renew. Energy 2018, 124, 3-10. [CrossRef]

72. Bar, R. Effect of interphase mixing on a water-organic solvent two-liquid phase microbial system: Ethanol fermentation. J. Chem. Technol. Biotechnol. 1988, 43, 49-62. [CrossRef]

73. Park, J.; Shiroma, R.; Al-Haq, M.I.; Zhang, Y.; Ike, M.; Arai-Sanoh, Y.; Ida, A.; Kondo, M.; Tokuyasu, K. A novel lime pretreatment for subsequent bioethanol production from rice straw-Calcium capturing by carbonation (CaCCO) process. Bioresour. Technol. 2010, 101, 6805-6811. [CrossRef]

74. Lee, Y.G.; Jin, Y.S.; Cha, Y.L.; Seo, J.H. Bioethanol production from cellulosic hydrolysates by engineered industrial Saccharomyces cerevisiae. Bioresour. Technol. 2017, 228, 355-361. [CrossRef]

75. Guerrero, A.B.; Ballesteros, I.; Ballesteros, M. The potential of agricultural banana waste for bioethanol production. Fuel 2018, 213, 176-185. [CrossRef]

76. Jin, X.; Song, J.; Liu, G.-Q. Bioethanol production from rice straw through an enzymatic route mediated by enzymes developed in-house from Aspergillus fumigatus. Energy 2019, 116395. [CrossRef]

77. Derman, E.; Abdulla, R.; Marbawi, H.; Sabullah, M.K. Oil palm empty fruit bunches as a promising feedstock for bioethanol production in Malaysia. Renew. Energy 2018, 129, 285-298. [CrossRef] 
78. Carrillo-Nieves, D.; Rostro Alanís, M.J.; de la Cruz Quiroz, R.; Ruiz, H.A.; Iqbal, H.M.N.; Parra-Saldívar, R. Current status and future trends of bioethanol production from agro-industrial wastes in Mexico. Renew. Sustain. Energy Rev. 2019, 63-74. [CrossRef]

79. Ussiri, D.A.; Lal, R. Miscanthus agronomy and bioenergy feedstock potential on minesoils. Biofuels 2014, 5, 741-770. [CrossRef]

80. Mood, S.H.; Golfeshan, A.H.; Tabatabaei, M.; Jouzani, G.S.; Najafi, G.H.; Gholami, M.; Ardjmand, M. Lignocellulosic biomass to bioethanol, a comprehensive review with a focus on pretreatment. Renew. Sustain. Energy Rev. 2013, 27, 77-93. [CrossRef]

81. Yang, H.; Shi, Z.; Xu, G.; Qin, Y.; Deng, J.; Yang, J. Bioethanol production from bamboo with alkali-catalyzed liquid hot water pretreatment. Bioresour. Technol. 2019, 274, 261-266. [CrossRef]

82. Wang, K.S.; Wu, C.H.; Creek, J.L.; Shuler, P.J.; Tang, Y. Evaluation of effects of selected wax inhibitors on wax appearance and disappearance temperatures. Pet. Sci. Technol. 2003, 21, 359-368. [CrossRef]

83. Hidayat, F.; Abdurrahman, M. A prospective method to increase oil recovery in waxy-shallow reservoir. IOP Conf. Ser. Mater. Sci. Eng. 2018, 306, 012040. [CrossRef]

84. Abdurrahman, M.; Ferizal, F.H.; Husna, U.Z.; Pangaribuan, L. Possibility of wax control techniques in Indonesian oil fields. AIP Conf. Proc. 2018, 1941.

85. Fernandiaz, R.; Amri, I.; Utama, P.S. Modeling of oil flows in Langgak field pipeline. J. Earth Energy Eng. 2019, 8, 12-20. [CrossRef]

86. Ellison, B.T.; Gallagher, C.T.; Lorimer, S.E. The physical chemistry of wax, hydrates, and asphaltene. In Proceedings of the Offshore Technology Conference, Houston, TX, USA, 1-4 May 2000.

87. Alves, B.F.; Pereira, P.H.R.; Nunes, R.D.C.P.; Lucas, E.F. Influence of solvent solubility parameter on the performance of EVA copolymers as pour point modifiers of waxy model-systems. Fuel 2019, 258, 116196. [CrossRef]

88. Ridzuan, N.; Adam, F.; Yaacob, Z. Evaluation of the inhibitor selection on wax deposition for Malaysian crude oil. Pet. Sci. Technol. 2016, 34, 366-371. [CrossRef]

89. Towler, B.F.; Jaripatke, O.; Mokhatab, S. Experimental investigations of the mitigation of paraffin wax deposition in crude oil using chemical additives. Pet. Sci. Technol. 2011, 29, 468-483. [CrossRef]

90. Xu, G.; Xue, Y.; Zhao, Z.; Lian, X.; Lin, H.; Han, S. Influence of poly(methacrylate-co-maleic anhydride) pour point depressant with various pendants on low-temperature flowability of diesel fuel. Fuel 2018, 216, 898-907. [CrossRef]

91. Zaky, M.T.; Mohamed, N.H.; Farag, A.S. Separation of some paraffin wax grades using solvent extraction technique. Fuel Process. Technol. 2011, 92, 2024-2029. [CrossRef]

92. Martínez-Palou, R.; de Lourdes Mosqueira, M.; Zapata-Rendón, B.; Mar-Juárez, E.; Bernal-Huicochea, C.; de la Cruz Clavel-López, J.; Aburto, J. Transportation of heavy and extra-heavy crude oil by pipeline: A review. J. Pet. Sci. Eng. 2011, 75, 274-282. [CrossRef]

93. Zhang, H.; Xiao, W. Pour point depressant (PPD) and flow improver additives (FIA) of crude oil and its study method progress. Adv. Mater. Res. 2012, 524-527, 1844-1847. [CrossRef]

94. Chanda, D.; Sarmah, A.; Borthakur, A.; Rao, K.V.; Subrahmanyam, B.; Das, H.C. Combined effect of asphaltenes and flow improvers on the rheological behaviour of Indian waxy crude oil. Fuel 1998, 77, 1163-1167. [CrossRef]

95. Pedersen, K.S.; Rønningsen, H.P. Influence of wax inhibitors on wax appearance temperature, pour point, and viscosity of waxy crude oils. Energy Fuels 2003, 17, 321-328. [CrossRef]

96. Deka, B.; Sharma, R.; Mandal, A.; Mahto, V. Synthesis and evaluation of oleic acid based polymeric additive as pour point depressant to improve flow properties of Indian waxy crude oil. J. Pet. Sci. Eng. 2018, 170, 105-111. [CrossRef]

97. Castro, L.V.; Vazquez, F. Copolymers as flow improvers for Mexican crude oils. Energy Fuels 2008, 22, 4006-4011. [CrossRef]

98. Soliman, E.A.; Elkatory, M.R.; Hashem, A.I.; Ibrahim, H.S. Synthesis and performance of maleic anhydride copolymers with alkyl linoleate or tetra-esters as pour point depressants for waxy crude oil. Fuel 2018, 211, 535-547. [CrossRef]

99. Wang, Z.; Bai, Y.; Zhang, H.; Liu, Y. Investigation on gelation nucleation kinetics of waxy crude oil emulsions by their thermal behavior. J. Pet. Sci. Eng. 2019, 181, 106230. [CrossRef] 
100. Huang, H.; Wang, W.; Peng, Z.; Li, K.; Gan, D.; Zhang, S.; Ding, Y.; Wu, H.; Gong, J. The effect of cooling processes on the yield stress of waxy model oil with nanocomposite pour point depressant. J. Pet. Sci. Eng. 2019, 175, 828-837. [CrossRef]

101. Huang, H.; Wang, W.; Peng, Z.; Ding, Y.; Li, K.; Li, Q.; Gong, J. The influence of nanocomposite pour point depressant on the crystallization of waxy oil. Fuel 2018, 221, 257-268. [CrossRef]

102. Sharma, R.; Mahto, V.; Vuthaluru, H. Synthesis of PMMA/modified graphene oxide nanocomposite pour point depressant and its effect on the flow properties of Indian waxy crude oil. Fuel 2019, 235, 1245-1259. [CrossRef]

103. Xie, M.; Chen, F.; Liu, J.; Yang, T.; Yin, S.; Lin, H.; Xue, Y.; Han, S. Synthesis and evaluation of benzyl methacrylate-methacrylate copolymers as pour point depressant in diesel fuel. Fuel 2019, 255, 115880. [CrossRef]

104. Yao, B.; Li, C.; Zhang, X.; Yang, F.; Sun, G.; Zhao, Y. Performance improvement of the ethylene-vinyl acetate copolymer (EVA) pour point depressant by small dosage of the amino-functionalized polymethylsilsesquioxane (PAMSQ) microsphere. Fuel 2018, 220, 167-176. [CrossRef]

105. Fang, L.; Zhang, X.; Ma, J.; Zhang, B. Investigation into a pour point depressant for shengli crude oil. Ind. Eng. Chem. Res. 2012, 51, 11605-11612. [CrossRef]

106. Monger-McClure, T.G.; Tackett, J.E.; Merrill, L.S. Comparisons of cloud point measurement and paraffin prediction methods. SPE Prod. Facil. 1999, 14, 4-16. [CrossRef]

107. Hammami, A.; Ratulowski, J.; Coutinho, J.A.P. Cloud points: Can we measure or model them? Pet. Sci. Technol. 2003, 21, 345-358. [CrossRef]

108. Towler, B.F.; Rebbapragada, S. Mitigation of paraffin wax deposition in cretaceous crude oils of Wyoming. J. Pet. Sci. Eng. 2004, 45, 11-19. [CrossRef]

(C) 2019 by the authors. Licensee MDPI, Basel, Switzerland. This article is an open access article distributed under the terms and conditions of the Creative Commons Attribution (CC BY) license (http://creativecommons.org/licenses/by/4.0/). 